\title{
PLANTAS MEDICINAIS E AROMÁTICAS MAIS UTILIZADAS PELA POPULAÇÃO DA REGIAO SUL DE CUIABÁ-MT EM 2005
}

Isanete Geraldini Costa Bieski ${ }^{1}$

\section{INTRODUÇÃO}

Atualmente um número cada vez maior de pessoas preocupadas com excesso das civilizações industriais, traduzidos em danos e ameaças à integridade da saúde física, mental e moral, recorre-se a Fitoterapia num movimento quase que instintivo de reconciliação com a natureza (PELT, 1979). No Brasil há três tipos de influência na formação da medicina tradicional: a colonização portuguesa; a participação indígena, de aspectos místico e terapêutico e a cultura negra proveniente da África (escravos), afirma CAMPOS (1995).

É de fundamental importância conhecer e preservar os biomas, uma das maiores riquezas do Brasil, com uma extensão territorial de 8.500 .000 quilômetros quadrados, com aproximadamente $40 \%$ da sua área coberta por floresta nativa (GIULIETTI et al., 2005), verdadeiro patrimônio genético, científico, tecnológico, econômico e cultural que precisa ser conhecido, pesquisado, valorizado e explorado racional e criteriosamente. Essa é uma condição indispensável para que se possa promover sua conservação e preservação perpetuando boas qualidades do meio ambiente para gerações futuras. Não se pode valorizar e preservar o que não se conhece (AMOROZO, 1998).

A diversidades de espécies medicinais, se constitui uma das mais importantes fontes de princípios ativos do planeta, por isso, as perspectivas do conhecimento das plantas medicinais pela comunidade tradicional, indígena, raizeiros, quilombolas são altamente promissoras.

1 Farmacêutica e Bioquímica, Doutora em Ciências da Saúde pela Faculdade de Medicina da Universidade Federal de Mato Grosso. Coordenadora do Curso de Farmácia da Faculdade do Vale do Juruena, Juína, Mato Grosso, Brasil. 
Por tanto catalogar, registrar corretamente informações sobre o uso de plantas medicinais, que ocorrem na flora regional, de comprovado valor terapêutico é fundamental para a fitoterapia brasileira (SILVA et al., 1992).

As dificuldades encontradas para avaliações precisas sobre o nível de perda de espécies são muito grandes no país. Mesmo assim, as listas de espécies ameaçadas e/ou extintas já aparecem com maior freqüência. Os esforços, até certo ponto isolados, conduzidos por algumas instituições no sentido de defender o patrimônio genético do país ainda estão longe de alcançar os objetivos desejados (GIULIETTI et al., 2005).

$O$ interesse acadêmico a respeito do conhecimento que estas populações detêm sobre plantas e seus usos têm crescido, após a constatação de que a base empírica desenvolvida por elas ao longo de séculos pode, em muitos casos, ter uma comprovação científica, que habilitaria a extensão destes usos à sociedade industrializada (FARNSWORTH, 1988).

Mato Grosso, possuidor de diversos trabalhos com plantas medicinais disponíveis à comunidade científica (CORRÊA, 1975; ALEXIADES, 1996; GUARIM NETO, 1996; CABELLERO, 2003). Porém, em todos eles, as plantas medicinais do Cerrado são discutidas junto com espécies de outros ambientes (Pantanal, Floresta Amazônica ou exóticos) e por isso não se tem um número exato de quantas são as ocorrentes no Cerrado de Mato Grosso (GUARIM, MORAIS, 2003). Diante disto, selecionar as espécies medicinais mais utilizadas pela população da região sul de Cuiabá-MT, visando preservar a sabedoria milenar oriunda do conhecimento tradicional, constitui o objeto a corroborar com dados científicos no mundo moderno.

\section{DELINEAMENTO EXPERIMENTAL}

Essa pesquisa foi desenvolvida na Região Sul da cidade de Cuiabá, capital do estado de Mato Grosso, Região Centro-Oeste do país. Cuiabá é o principal pólo industrial, comercial e de serviços do estado. É conhecida como "cidade verde", por causa da grande arborização. Situa-se na margem esquerda do rio de mesmo nome e forma uma conurbação com o município vizinho, Várzea Grande. Segundo estimativas de 2016 feitas pelo Instituto 
Brasileiro de Geografia e Estatística, a população de Cuiabá é de 585.367 habitantes, enquanto que a população da conurbação é de 856.706; já sua região metropolitana possui 887.410 habitantes e o colar metropolitano quase 1 milhão; sua mesorregião possui 1.105.132 habitantes, o que faz de Cuiabá uma pequena metrópole no centro da América do Sul. O município é cercado por três grandes biomas: a Amazônia, o Cerrado e o Pantanal; está próximo da chapada dos Guimarães e ainda é considerado a porta de entrada da floresta amazônica. A vegetação predominante no município é a do cerrado, desde suas variantes mais arbustivas até as matas mais densas à beira dos cursos d'água (MATO GROSSO, 2010).

A pesquisa foi realizada em residências sorteadas da população cadastrada nas unidades de saúde da região sul de Cuiabá, onde participaram 693 pessoas (homens e mulheres), que aceitaram participar da pesquisa após a explicação da natureza e finalidade do trabalho e após assinatura de Termo de Consentimento Livre e Esclarecido (TCLE). Os formulários foram aplicados pela pesquisadora e 3 acadêmicas do curso de ciências biológicas da Universidade de Cuiabá (UNIC), no período de novembro de 2004 a janeiro de 2005.

O presente trabalho constitui um recorte da pesquisa da pesquisadora destacando as espécies mais utilizadas pelos sujeitos da pesquisa em seu estudo qualitativo de cunho etnobotânico, onde foram levantados dados do uso tradicional das plantas medicinais pela população. Os métodos etnobotânicos utilizados neste trabalho seguem recomendações e técnicas modernas que facilitam o estabelecimento de interseções entre as áreas. A pesquisa foi realizada em unidades de saúde, onde participaram 693 usuários da região sul de Cuiabá no período de novembro de 2004 a janeiro de 2005 e preferencialmente, entrevistadas as mulheres, que são as responsáveis pelas hortas domésticas em cada propriedade.

\section{RESULTADOS E DISCUSSÃO}

Para esse capítulo, não foi possível descrever todos os resultados da pesquisa (BIESKI, 2005) e assim serão descritos apenas as 
plantas medicinais mais citadas na pesquisa com os 693 cadastrados nas unidades de saúde da Região Sul de Cuiabá e que foram sorteados para participar da pesquisa, a pesquisa possibilitou identificar, porém para esse capitulo selecionou-se as mais utilizadas e que já são validadas pela ANVISA. As plantas mediicnais selecionadas seguem descrições conforme compêndio de plantas medicinais do curso de plantas medicinais da UFLA-MG escrito por Cardoso et al. (2000), em um apainhado de vários autores (HERTWIG, 1991; BREMNESS, 1993; CARVALHO JÚNIOR, MING, L. C.; SCHEFFER, 1994; CASTRO, CHEMALE, 1995; TESKE, TRENTINI, 1995; CORRÊA, BATISTA, 1998; ROGER,1998; SIMÕES, 1998; FRANCO, 1999; MARTINS, 2000; LORENZI, MATOS, 2002).

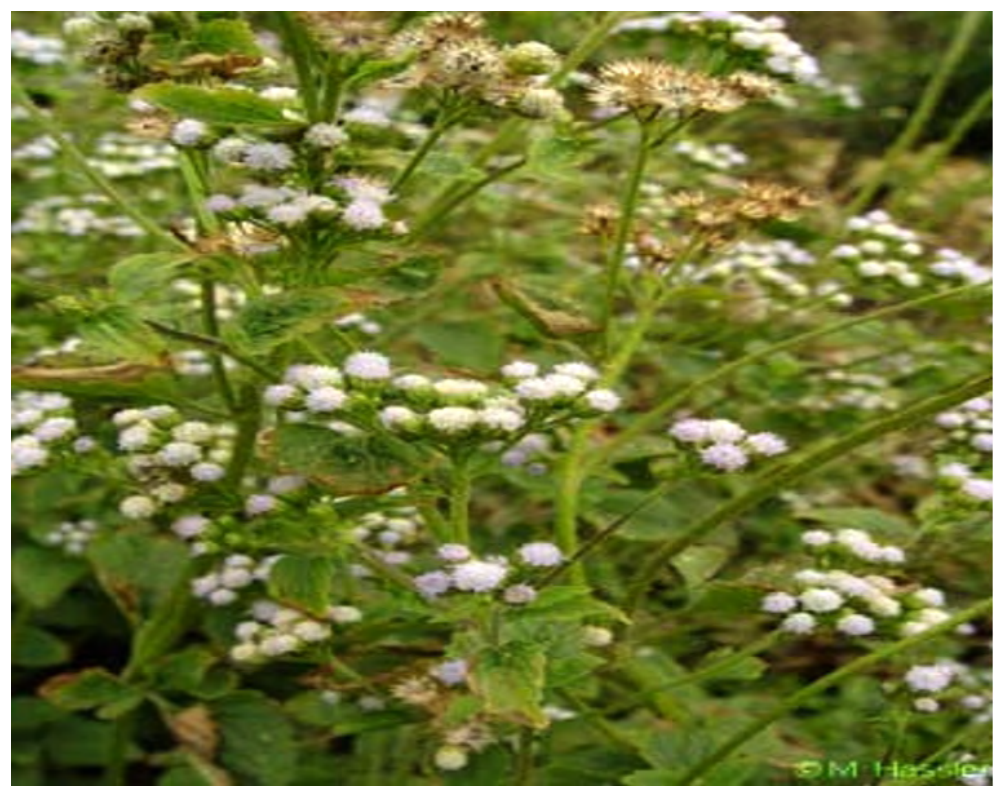

Figura 1. Ageratum conyzoides L. (MENTRASTO

Familia: Asteraceae

Sinonímia: Camará-opela, caatinga-de-barão, catinga-de-bode, erva-de-santa-lúcia, erva-de-são joão, erva-de-são-josé, erva-maria, maria-preta, picão-roxo, são-joão, mentraço, mentraz, mentruz.

Origem: Centro Oeste e Sudeste do Brasil.

Descrição: Planta anual, herbácea, ereta, caules revestidos de 
pelos alvos, medindo $30 \mathrm{~cm}$ a $1,0 \mathrm{~m}$ de altura. As inflorescências são terminais, em forma de capítulos. Folhas opostas, membranáceas, pubescentes, de pecíolos longos, com 4 a $9 \mathrm{~cm}$ de comprimento. Vegeta em qualquer tipo de solo, mas desenvolve melhor em solos férteis e com elevado teor de matéria orgânica.

Uso farmaco-terapêutica: Reumatismo, diarréia, cólicas.

Propagação: Por sementes, sua germinação é alta.

Parte utilizada: Toda a planta.

Constituintes químicos principais: óleo essencial, compostos cumarínicos e benzofuranas, alcalóides, flavonas, flavonóides e cromonas.

Formas farmacêuticas habituais: Infusão, chás.

Indicação, Preparo e Posologia: Cólicas uterinas, diarréia e disenteria, flatulência, reumatismo agudo, artrose, contusões, ferimentos abertos, afecções das vias urinárias, gases e estimulante do apetite. Tem uma ação vasodilatadora e antiespasmódica devido seus componentes serem derivados da benzopirena.

Uso interno: chá por infusão $20 \mathrm{~g}$ por um litro de água, tomar 4 a 5 xícaras por dia.

Uso externo: como cataplasma sobre as articulações no caso de reumatismo e artrites.

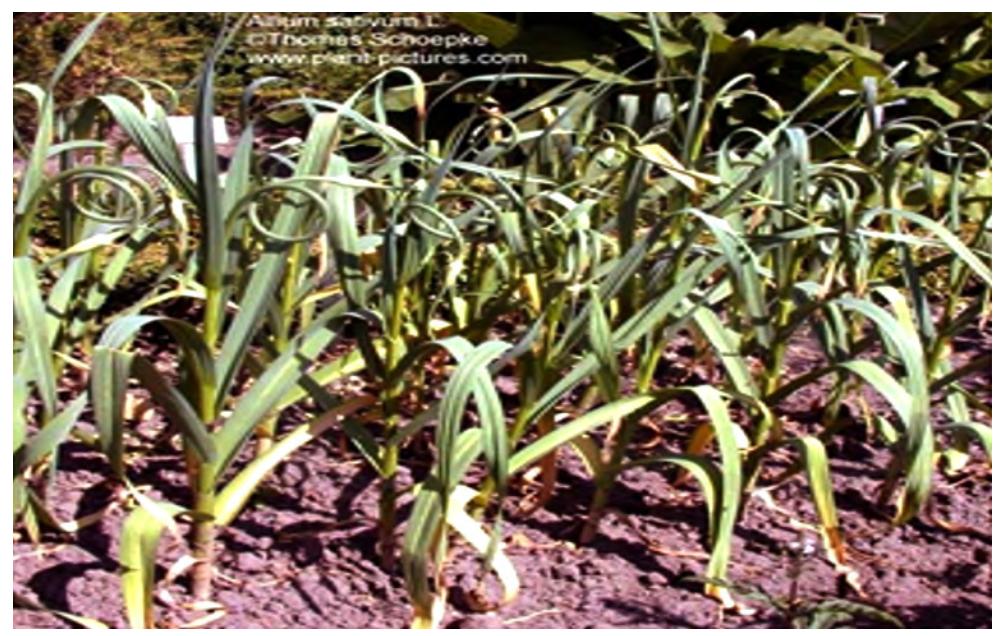

Figura 2. Allium sativum L. (Alho) 
Família: Amaryllidaceae

Fonte: Pharmakobotanik

Sinonímia: Ajo (Espanha); Aglio (Itália); Ail (França); Garlic (Inglaterra)

Origem: Europa Meridional e Oriente Médio.

Descrição: Erva culinária e medicinal, com altura de até $70 \mathrm{~cm}$, possui folhas estreitas e iguais. Suas flores miúdas, brancas e pouco cheirosas, nascem na parte terminal do caule. O bulbo é um corpo oval, formado por alguns gomos ou "dentes", e sendo constituído por uma massa consistente e aquosa de sabor e cheiros fortes.

Uso farmaco-terapêutica: Expectorante, Sudorífico. bronquite crônica, tuberculose, gangrena pulmonar, hemoptise, reumatismo.

Propagação: Por bulbos

Parte utilizada: Bulbos.

Constituintes químicos principais: Aliicina, inulina, nicotinamida, galantamina, ácidos fosfórico e sulfúrico, vitaminas A, B e C, proteínas e sais minerais.

Formas farmacêuticas habituais: Ungüento, óleo, infusão, cataplasma, decocção.

Indicação, Preparo e Posologia:

Ungüentos- (calos) misturar a polpa do alho amassado em óleo de oliva. Este ungüento de ser aplicado sobre o local, protegendo-o com gaze.

a. Insônia- esmagar um dente de alho em uma xícara de leite quente. Deixar em infusão por 10 minutos e após beber.

b. Cataplasma- (reumatismo) espremer alguns dentes de alho, colocando sobre uma lã quente. Aplicar sobre a região afetada.

c. Vermes-ferver, por 1 minuto, em leite açucarado, alguns dentes de alho amassados. Tomar 2 a 3 colheres ao dia.

d. Inflamação na garganta - Usar um dente de alho batido, o sumo de limão assado e uma colher de mel de abelha. Mistura-se e aplica-se na região interna da garganta. 


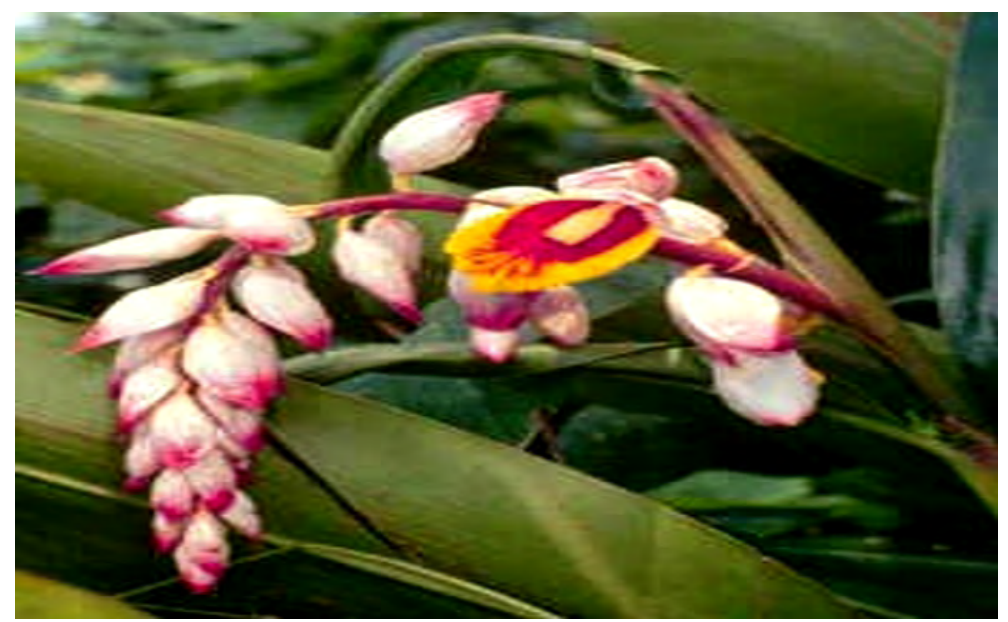

Figura 3. Alpinia zerumbet (pers.) B.L. Burtt. \& R. M. (Colônia) Fonte: Jardim de flores, 2005.

Família: Zingiberaceae

Outras espécies: Alpinia zerumbet (pers.) B.L. Burtt. \& R. M.

Siniminia: (Alpinia speciosa K. Schum., Catimbium speciosum J.C. Wendel, Languas speciosa Merril) (SPOERKE, SMOLINSKE,1990).

Sinonímia: paco-seroca, cuité-açu, pacova, colônia, vindicá, bastão-do- imperador, flor-da-redenção.

Origem: Ilhas da Ásia Oriental (ALMEIDA, 1993:148).

Descrição: Alpinia zerumbet (Pers.) B.L. Burtt. \& R.M.Sm. é planta herbácea, robusta, perene, com colunas de 2 a 3 metros de altura, lisas, verde-claras, agrupadas em touceiras. Folhas lanceoladas oblongas, pontudas, invaginantes, verde-luzidias, de margens ciliadas de 50 a $70 \mathrm{~cm}$ de comprimento sobre 10 a 12 de largura. Flores ligeiramente aromáticas, dispostas em cachos grandes, amarelo-róseas com três lobos e um grande lábio. Cápsula subglosa, de $2 \mathrm{~cm}$ de diâmetro, polispémica (ALMEIDA, 1993)

Uso farmaco-terapêutica. A Alpinia galanga Will. é usada na Índia como afrodisíaco e estimulante respiratório, principalmente em crianças (LEWIS, ELVIN-LEWIS, 1977). Pesquisa para a seleção das plantas mais usadas na medicina popular do Ceará, visando à recuperação de informações para o Banco de Dados de Plantas Medicinais da CEME, destaca a Alpinia zerumbet (Pers.) B.L. Burtt. \& R.M.Sm., dentre as classificadas como calmantes (MATOS, ALII ,1984). 
Propagação: A propagação de alpinia se dá por meio da divisão de rizomas.

Parte utilizada: Informantes do Pernambuco, de Sergipe, do Pará e de São Paulo, apontaram o emprego da colônia como sedativo e, ainda, o uso da flor conservada em álcool, passado na nuca e testa para curar dor de cabeça, além do costume de triturar o rizoma e dar a cheirar a asmáticos em crise.

Constituintes químicos principais: Alcalóides e fenóis livres em Alpinia nutans (DI STASI, ALII, 1989; MENDONÇA, ALII, 1988). Óleo essencial contendo cineol, eugenol, pineno, éter metílico, ácido cinâmico, cadineno; galangina; éter metílico de galangina; canferina; bassorina; amido; matérias mucilaginosas e resinosas em Alpinia officinarum Hance (COIMBRA, DINIZ, 1943). Alpinetina, cardamonina, cânfora. Esterosídeos flavonóides. Sesquiterpenos, fenilalquicetonas, compostos flavônicos, resina, taninos (FITOTERAPIA, 1998).

Indicação, Preparo e Posologia: Quanto aos usos na medicina popular do gênero Alpinia, a literatura que trata desse assunto diz ser usada para vários fins, tais como: diurética, carminativa, estomáquica, anti-emética, espasmolítica, antiinflamatória, antiofídica, anti-histérica, vermífuga, no combate ao reumatismo e como tônico geral (CRUZ, 1965; ALMEIDA, 1993).

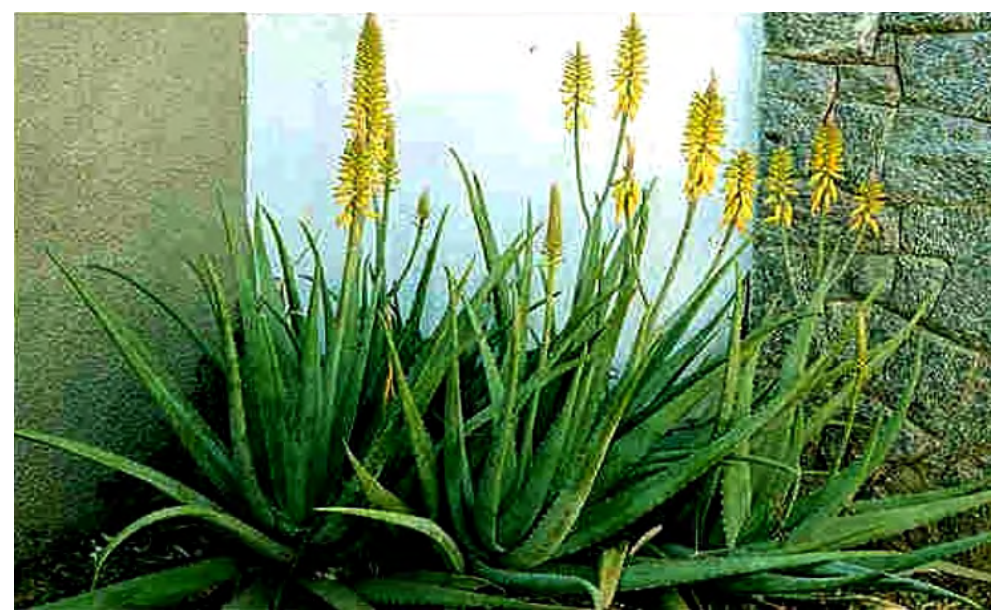

Figura 4. Aloe vera L. (Babosa)

Fonte: Flowersociety 
Família: Asphodelaceae

Outras espécies: Aloe barbadensis Mill. Aloe arborescens Mill.

Sinonímia: Babosa folha miúda; Babosa folha grande; Erva Babosa; Caraguatá; Aloé

Origem: Sul da África; Regiões quentes da Europa e América do Sul.

Descrição: Planta perene, herbácea, estolonífera, raízes longas e de um amarelo intenso, internamente. Caule tenro, ereto ou levemente decubentes. Folhas carnosas, simples, alternas, sésseis, tenras, grossas, longas, lanceoladas, acuminadas, bordos com fortes dentes espinhosos e dispostos em grandes rosetas. Esta espécie tem as folhas verde-escuras e sem manchas em ambas às faces. Flores vermelhas, actinomorfas, hermafroditas com o perigônio tubuloso formado por seis tépalas. Estames em número de 6, mais longos que as tépalas, com filetes subulados e antera oblongas. Ovário trilocular e trígono, com os lóculos pluriovulados e o estilete filiforme. Inflorescência em racimos. Frutos na forma de cápsulas trígonas e deiscentes, com três lóculos. Sementes pequenas, aladas, numerosas e escuras. Não tolera solos encharcados. Exigente em solo fértil para um bom rendimento. Responde bem a fósforo e potássio.

Uso farmaco-terapêutica: Queimaduras, antioftálmica, entoses, contusões, retites, hemorróidas, dores reumáticas e queda de cabelo.

Propagação: Perfílhos com raiz

Parte utilizada: Folha; Seiva e polpa.

Constituintes químicos principais: Ácido tânico, acético, gálico e málico; aloina; dapomina; espinefrina; serotonina; tiramina; além de vitaminas, carboidratos, proteínas e sais minerais.

Formas farmacêuticas habituais: Resina, polpa, tintura e suco das folhas.

Indicação, Preparo e Posologia: antiinflamatória; analgésicas; antiséptica; emoliente; adstringente; colerética; vulneraria e anticancerigena.

Suco - Uso interno do suco fresco como anti-helmintico;

Cataplasma - aplicar sobre queimaduras 3 vezes ao dia;

Supositório - em retites hemorróidas;

Resina - é a mucilagem após a secagem. Prepara-se deixando as folhas penduradas com a base cortada para baixo por 1 ou 2 dias, 
esse sumo é seco ao fogo ou ao sol, quando bem seco, pode ser transformado em pó. Tomar 0,1 a 0,2g. O pó dissolvido em água com açúcar, como laxante;

Tintura - usam-se 50g de folhas descascadas, trituradas com $250 \mathrm{ml}$ de álcool e $250 \mathrm{~mL}$ de água, a tintura é coada em seguida. Deve ser utilizada sob a forma de compressas e massagens nascontusões; entoasses e dores reumáticas.

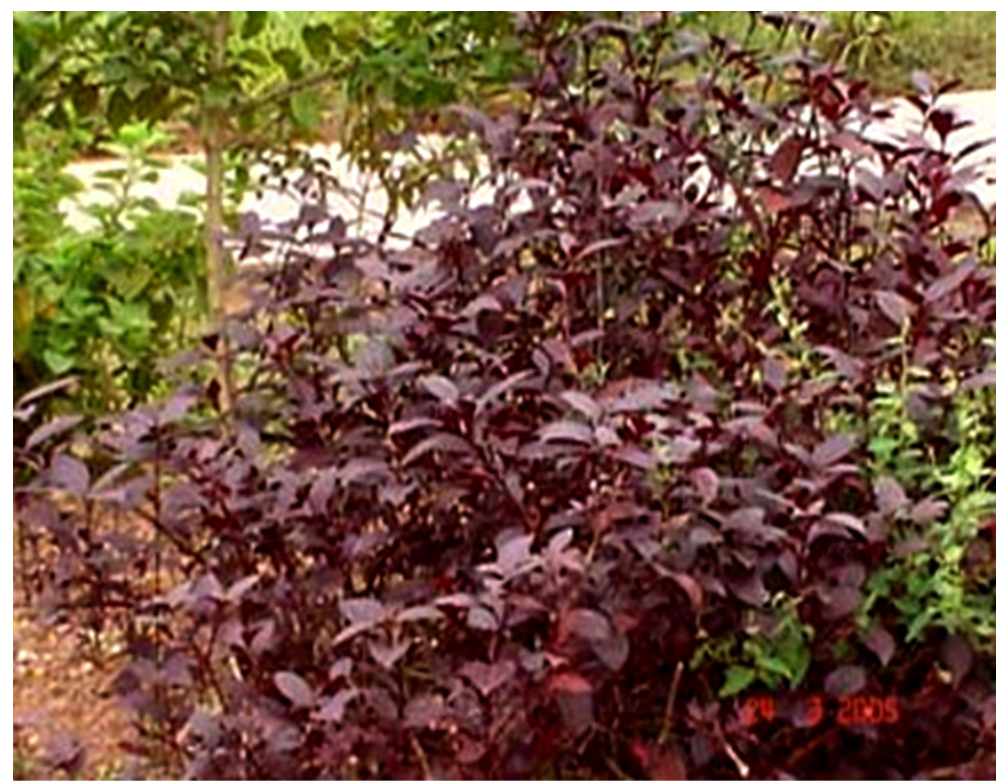

Figura 5. Alternanthera brasiliana Kunt. (Doril)

Fonte: BIESKI, 2005.

Família: Amaranthaceae

Sinonímia: Anador; melhoral. Origem: Brasi.

Descrição: Planta herbácea ereta de 50 a $80 \mathrm{~cm}$ de altura com folhas oval-alongadas, vermelho-arroxeada, planas. Inflorescência globosa, pequena celulóicas, verde-esbraquiçadas.

Uso farmaco-terapêutica: Como tratamento de hemorróidas e dores em geral.

Propagação: Por enraizamento de ramos herbáceos.

Parte utilizada: Folhas.

Constituintes químicos principais:

Formas farmacêuticas habituais: Infusão, decocção (chás). 
Indicação, Preparo e Posologia: No combate ao béquico e as dores.

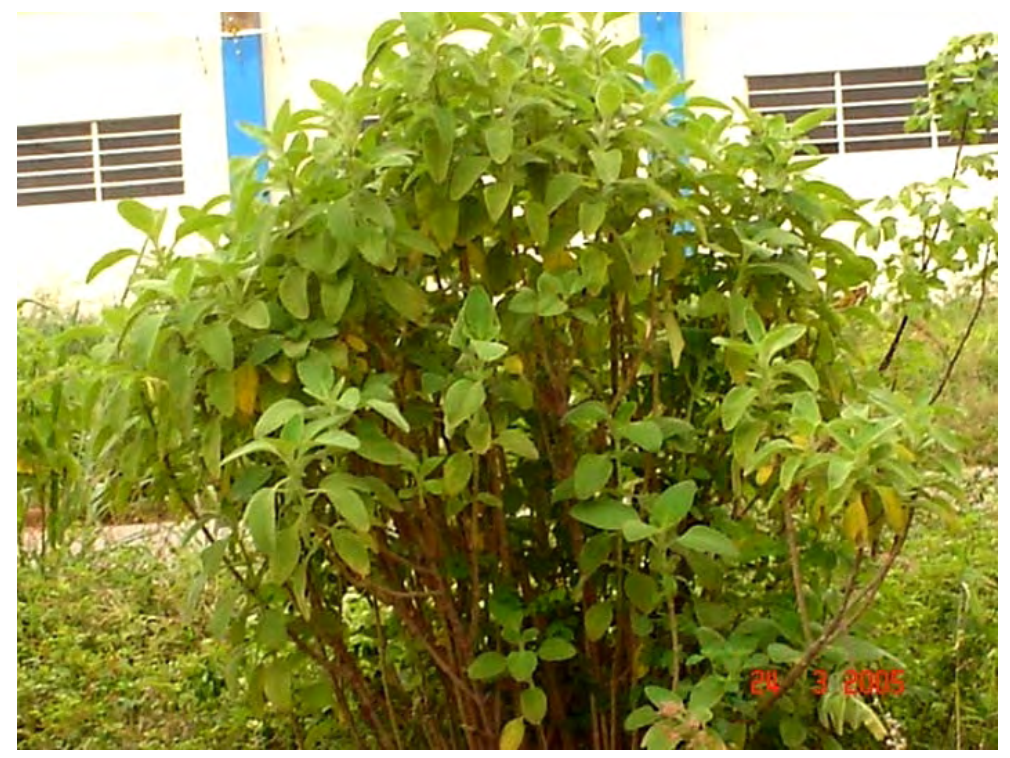

Figura 6. Plectranthus barbatus (Andr.) Benth (Boldo)

Fonte: BIESKI, 2005.

Família: Lamiaceae

Sinonímia: Alumã, boldo, boldo chileno, boldo falso, boldo de jardim, boldo nacional, boldo silvestre, boldo do reino, erva cidreira, hortelã homem, hortelã gorda, malva amarga, malva santa, sete dores, sete sangrias, tapete de Oxalá.

Origem: Chile

Descrição: Erva perene, de ramos decumbentes a eretos, quadrangulares, semi-suculento. Folhas opostas, ovado-oblongas, grossas, de até $12 \mathrm{~cm}$ de comprimento por $8 \mathrm{~cm}$ de largura, de margem serrada, pilosas em ambas as faces, curto-pecioladas. Flores hermafroditas, diclamídeas, pentâmeras, fortemente zigomorfas, azul-violáceas, agrupadas em longasinflorescência eretas, do tipo racemo. Cálice com um dos lobos largo, subdecorrente no tubo; corola de até $1,7 \mathrm{~cm}$ de comprimento, tubo curvo, estreitado na porção mediana e na vincular na porção superior; estames de tamanho desigual, filetes curvos acompanhando a corola; estilete glabro, bifurcado, de ramos iguais. Prefere solos ácidos e ricos em 
matéria orgânica, portanto o boldo não deve receber calagem pesada. Não tolera solos encharcados.

Uso farmaco-terapêutica: Má digestão, útil na litíase biliar e nas afecções do fígado.

Propagação: Por enraizamento de ramos herbáceos.

Parte utilizada: Folhas

Constituintes químicos principais: Glicosídeo, glocobaldina ou boldoglucina, alcalóide boldina.

Formas farmacêuticas habituais: Decocção

Indicação, Preparo e Posologia: Tem propriedades diuréticas, estomáquica, colagogas e coloréicas. É usado como estimulante biliar em doenças do fígado, no tratamento de cálculos biliares e como diurético.

Cálculos biliares e colecistite: decocção-ferver $15 \mathrm{~g}$ de folhas de boldo do nacional em 1 litro de água, por dois minutos. Coar, adoçar e beber 2 xícaras por dia.
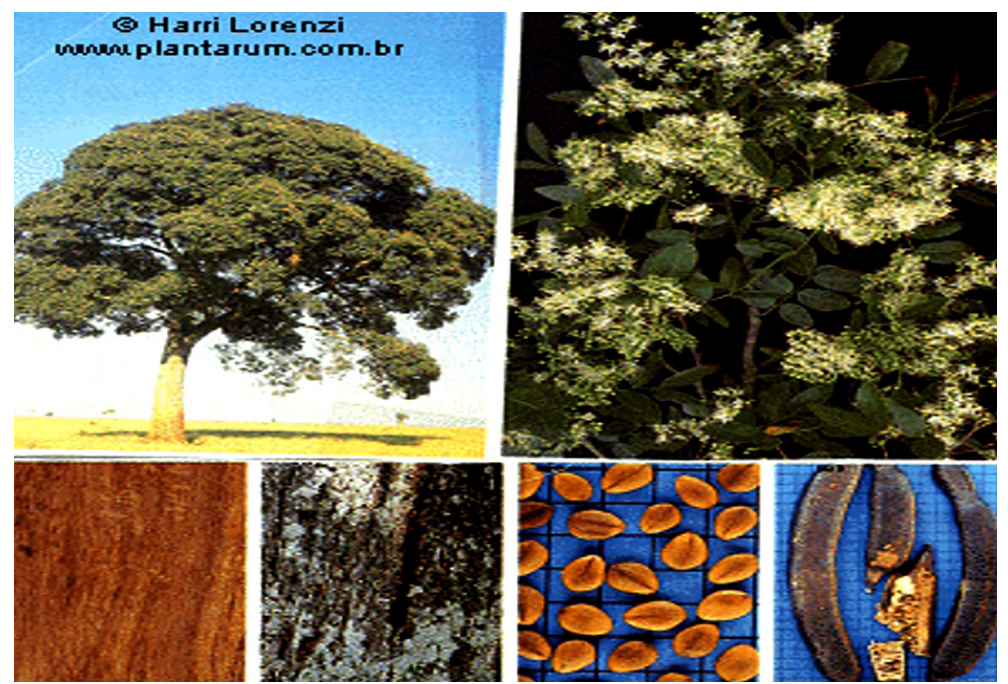

Figura 7. Copaifera reticulada Ducke. (Copaíba)

Fonte: Lorenzi, 2008

Família: Fabaceae

Sinonímia: copaíba branca, copaíba verdadeira, mari-mari, copaíba jutaí.

Origem: Amazônia Brasileira. 
Descrição: Árvore alta de até 30m de altura de casca rugosa pardacenta, folhas com raque alado, alternas, compostas, folíolos, assimétricos, elíptico- oblongos, $2-5,5 \mathrm{~cm}$ de comprimento por $1-5,5 \mathrm{~cm}$ de largura, inflorescência espiciforme, flores sésseis alvacentas ou amarelo- esverdeadas, fruto legume, $1,5-2 \mathrm{~cm}$ de diâmetro, semente envolvida por arilo amarelo.

Uso farmaco-terapêutica: anti-inflamatório, cicatrizante, tétano, dermatoses, reumatismo, leucorréia, contusões; herpes; inflamações da garganta; câncer, catarros.

Propagação: por sementes, de preferência sem o arilo.

Parte utilizada: óleo extraída do lenho.

Constituintes químicos principais: ácido copaífero acubeno, ß-cariofileno, ß- elamino, ß bisaboleno, cânfora.

Modo de usar: colocar o óleo na parte afetada puro ou misturado com outras substâncias; misturado com óleo de andiroba-uso local; gotas do óleo com mel de abelha; cápsulas.

Observações: internamente deve ser usado com cautela. 0 óleo é usado para apressar a cicatrização do cordão umbilical, evitando tétano. Os indígenas costumam aplica-lo sobre a pele, visando repelir insetos.

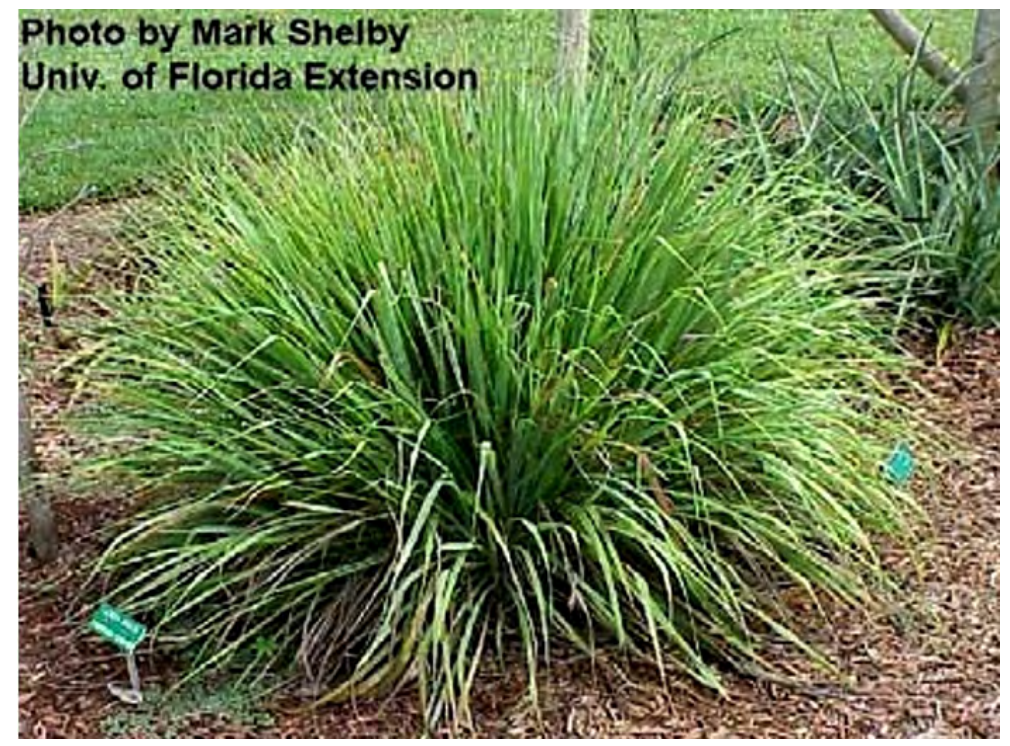

Figura 8. Cymbopogon citratus (DC. ex Ness) Stapf. (Capim-limão)

Fonte: SARASOTA, 2005 


\section{Família: Poaceae}

Sinonímia: Capim-cidreira, erva cidreira, chá-de-estrada, capim-cidrão e citronela-de-java, capim cidró, capim santo, capim cheiroso, capim catinga.

Origem: Índia

Descrição: Erva aromática anual, bianul ou perene, com até 2 m de altura, possuindo rizoma curto e horizontal com raízes fortes e finas, formando touceiras compacta. Suas folhas são eretas ou curvas invaginantes, medindo aproximadamente $1 \mathrm{~m}$ de comprimento por $1,5 \mathrm{~cm}$ de largura, apresentando bainha de cor roxa na base e branco esverdeado na parte interna. Suas flores são hermafroditas e seu fruto é aquênio. Trata-se de planta bastante odorífera, que produz um óleo essencial idêntico ao da erva-cidreira ou do limão, chamado óleo de citronela. É uma planta excelente para proteger o solo de erosão. O capim limão prefere climas quentes e úmidos, com chuvas bem distribuídas e temperatura média elevada. Pode ser cultivado em qualquer tipo de solo, desde que bem drenado e fértil.

Uso farmaco-terapêutica: Calmante

Propagação: Por divisão de touceiras.

Parte utilizada: Folhas e rizoma. De preferência, deve ser usada a folha fresca.

Constituintes químicos principais: Óleo essencial contendo 75 a 85\% de citral e seus isômeros geranial e neral.

Formas farmacêuticas habituais: Chá, Infusão.

Indicação, Preparo e Posologia: Insônia, nervosismo, dores de cabeça. Bactericida, calmante, analgésico, diarréia, problemas renais, carminativa, estomáquica, antitérmica. Determina uma diminuição da atividade motora, aumentando o tempo de sono. $A$ atividade antibacteriana está associada ao citral.

Infusão- 4 xícaras (café) de folhas picadas em 1 litro de água. Tomar 1 xícara 2 a 3 vezes ao dia;

Repelentes de insetos - colocar as folhas em um saco de pano e guardar junto das roupas como aromatizante e para repelir os insetos;

Os rizomas frescos auxiliam na limpeza dos dentes e gengivas - coloque uma colher de sobremesa de rizoma fatiado em uma xícara de água em fervura. Desligue o fogo, coe e deixe esfriar e 
faça bochechos, de 2 a 3 vezes ao dia. (As folhas e rizomas - não é necessário ferver muito, nem deixar em água quente por muito tempo);

A utilização durante a gestação e lactação é recomendada, estimulante lácteo.

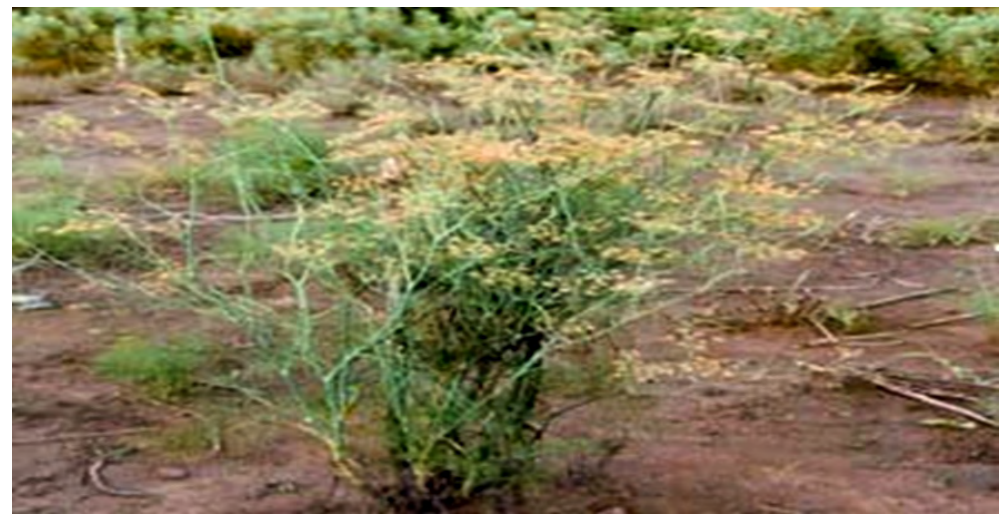

Figura 9. Foeniculum vulgare Mill. (Funcho)

Fonte: LEAO, 1998.

Família: Apiaceae. Sinonímia: Erva-doce, fiolho, fiolho-de-florena, fiolho doce.

Origem: Mediterrâneo

Descrição: Planta de 1 a 2 metros de altura, vede-glauca, exalando um aroma agradável. Haste direita, cilíndrica, glabra, lisa, estriada, ramosa. Folhas alternas, amplas, recortadas em segmentos assovelados, quase capilares; pecíolos amplexicaules. Flores amarelas, pequenas, em umbelas terminais, grandes, raios numerosos e grandes. Prefere clima temperado com verões quentes. Gosta de solos profundos, férteis e bem drenados. Solos com bons níveis de fósforo e potássio são necessários para uma boa produção de sementes, sendo que uma adubação nitrogenada aumenta ligeiramente o teor de essência dos frutos.

Uso farmaco-terapêutica: Prisão-de-ventre. As folhas e frutos atuam como carminativos, antiespasmódico, tônico, galactogogo, expectorante, emenagogo, estomáquica, purificante, antiinflamatório.

Propagação: Por sementes

Parte utilizada: Folhas, frutos e raízes.

Constituintes químicos principais: Óleo essencial 1,5 a 6\% Fun- 
chona (20\%) anetol (50 a 87\%), limoneno, foenculina, mucilagem, taninos, pectinas, flavonóides, tocoferois, cumarinas.

Formas farmacêuticas habituais: Infuso, decocto, pó, extrato fluido, alcoolato, tintura e xarope.

Indicação, Preparo e Posologia: Carminativa, digestivo, diurético, tônico geral, antiespasmódico (cólicas de crianças).

Infusão- 1 xícara (café) de frutos secos em $1 / 2$ litro de água. Para gases tomar 1 xícara de (chá) de 6 a 6 horas ao dia.

Digestivo- 1 xícara a cada meia hora, 2 horas antes das refeições.

Decocção-ferver por 5 minutos 1 colher de (chá) de sementes em $100 \mathrm{ml}$ de água. Dar a criança no intervalo das mamadas (cólicas).

Decocção- 15g de raiz em 1 litro de água. Tomar várias vezes ao dia, por 15 dias (diurético).

Vinho medicinal-(tônico) macerar por 10 dias, $30 \mathrm{~g}$ de sementes em 1 litro de vinho coar e tomar 1 cálice antes de dormir.

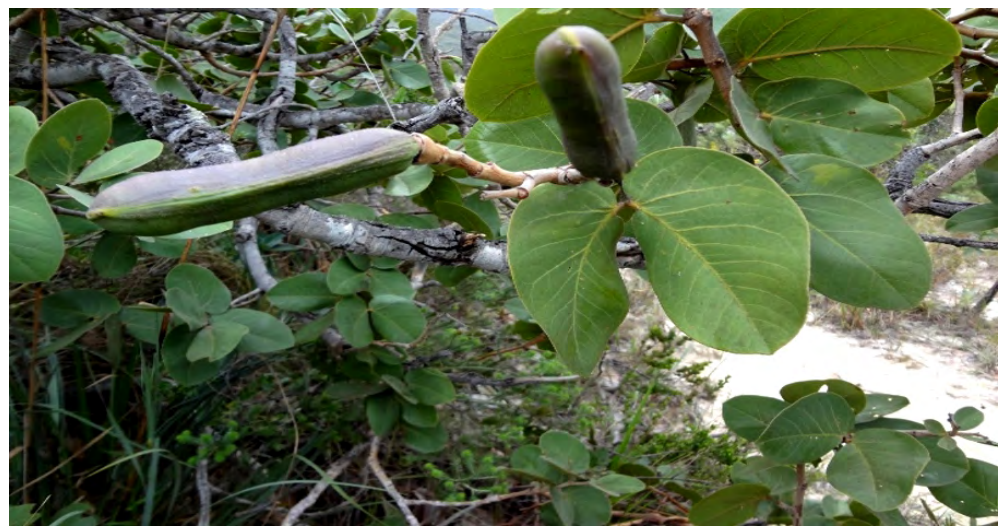

Figura 10. Hymenaea courbaril L. (Jatobá)

Fonte: Lamar, 2017.

Família: Fabaceae

Sinonímia: jataí, jutaí, jataíba, jataiba-peba, jataiba-uva, jataúba, juteí, jatel, jati, jassaí, jatobá de anta, jatobá de porco, jatabá trapuca, jetaí, jetaíba, jupiti, jutaí-açu, árvore-copal-do-Brasil, abotii-timbaí, jataici.

Origem: Pará, Rondônia e Maranhão. 
Descrição: Árvore de até 40m de altura, de casca áspera, castanho-clara ou acinzentada, com manchas de cores diversas de onde exsuda uma resina, copa ampla, esgalhada de ramificação densa; folhas compostas, alternas, pecioladas, bifoliadas, folíolos alternos, coreáceas, bilobados, em forma de lança ou ovais, glabros; inflorescência em panículas terminais; flores creme-alaranjadas; fruto vagem, oblonga ou achatada, grossa, indeiscente, pericarpo glabro, rugoso, duro, opaco ou pouco lustroso, castanho- avermelhado, contendo 2-5 sementes lisas, escuras, irregulares, recobertas por uma polpa comestível, amarela-clara, farinácea, adocicada.

Uso farmaco-terapêutica: balsâmico, inapetência, atonia gástrica, inflamação da bexiga e próstata, cistite crônica ou aguda, coqueluche, blenorragias; vermífugo, hemostática, peitoral, adstringente, disenteria, dispepsia, cólicas; escarros de sangue; asma, tosse, laringite e outras, afecções das vias respiratórias, expectorante, fortificante, úlceras bucais e dores localizadas.

Propagação: por sementes.

Parte utilizada: seiva e casca; resina; raiz; galhos.

Constituintes químicos principais: ésteres dos ácidos benzóico e cinâmico, catequina e óleos essenciais.

Modo de usar: decócto; com mel de abelha; aplicação local.

Observações: $O$ tronco e os ramos do jatobá exsudam uma resina de aroma parecido ao do incenso. "Jurássica ou copal da América" utilizada na produção de verniz. A seiva com água e açúcar é refrigerante.

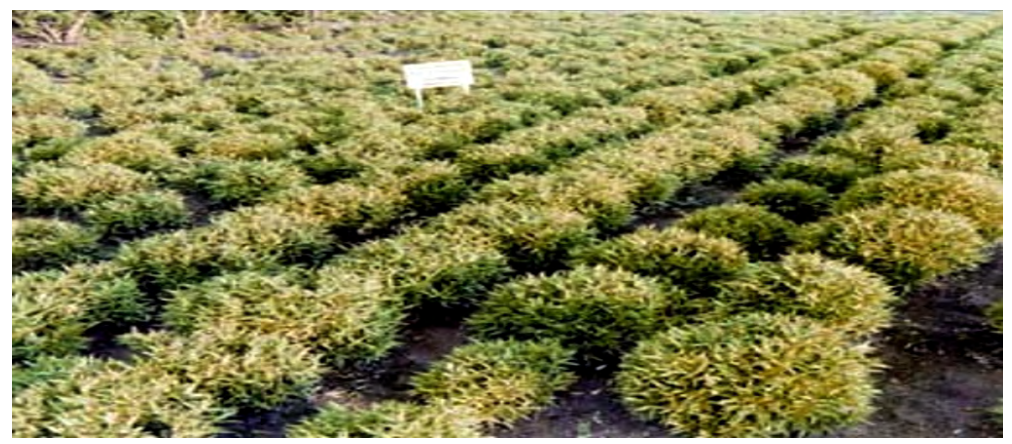

Figura 11. Justicia pectotalis var. plepoph (Anador)

Fonte: Leão (1994) 
Família: Acanthaceae

Sinonímia: Chambá, Anador.

Origem: Região Amazônica

Descrição: pequena erva sempre verde, suberecta, com ate $40 \mathrm{~cm}$ de altura. Flores simples, membranáceas, estreita e longa, medindo de 3 a $10 \mathrm{~cm}$ de comprimento. Flores de coloração mariscada, muito pequena. Fruto do tipo cápsula descente. Toda planta desprende um forte cheiro de cumarinas. Algum tempo depois da colheita.

Propagação: Por estaquias ou pequenas porções dos ramos já enraizados.

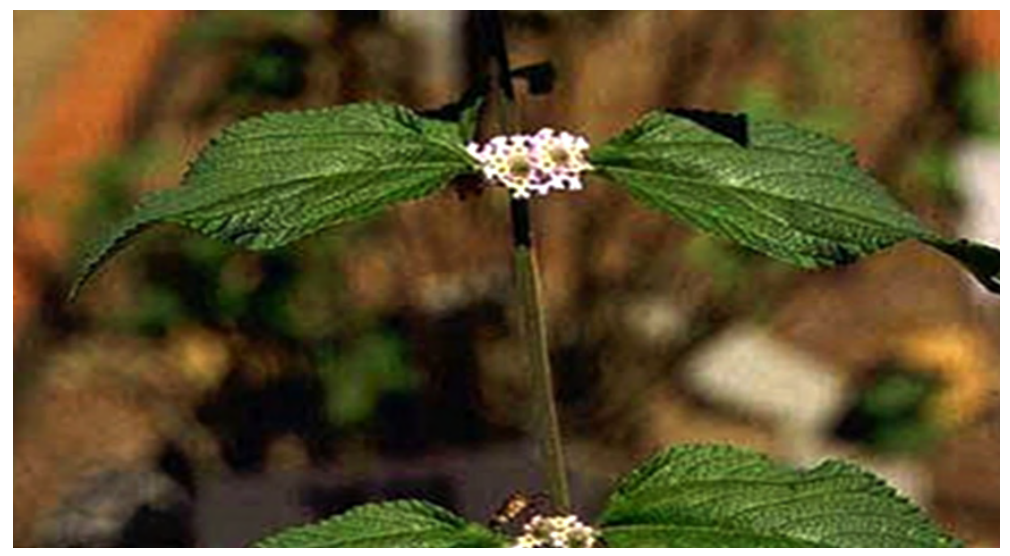

Figura 12. Lippia alba (Mill) N. E. Brown (Erva-cidreira)

Fonte: Bieski, 2005

\section{Família: Verbenaceae}

Sinonímia: Alecrim-do-campo, alecrim-selvagem, alecrim, cidreira-brava, falsa-melissa, capitão do mato, salva limão, sálvia da gripe.

Origem: América do Sul.

Descrição: É um subarbusto bianual medindo de 1 a $2 \mathrm{~m}$ de altura, bastante ramificada dicotomicamente; caule herbáceo de cor castanho claro; folhas de cor verde claras a escuro, nervadas, oblongo-agudas, opostas, abertas, possui cheiro forte aromático. Das folhas exala um cheiro característico, flores rosea-violáceas, reunidas em umbelas; raízes fasciculadas, devido seu tipo comum de multiplicação assexuada. Prefere regiões subtropicais, sem excesso de calor ou frias, vegeta em solos arenosos. 
Uso farmaco-terapêutica: Cólicas (dor de barriga), digestivo, Propagação: por enraizamento de ramos herbáceos.

Constituintes químicos principais: Tanino, resina, princípio amargo.

Formas farmacêuticas habituais: Extrato, infuso, decocto.

Indicação, Preparo e Posologia: Espasmos, estomáquicos, carminativa.

Infusão- 1 colher (sopa) de folhas frescas para cada $1 / 2$ litro de água. Tomar 4 a 6 xícaras de chá ao dia.

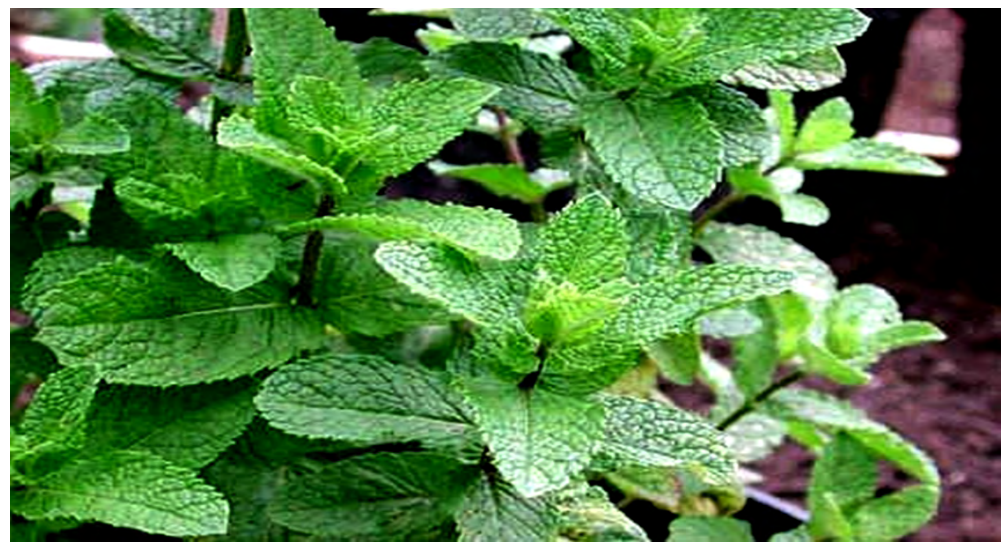

Figura 13. Mentha villosa (Mentha)

Fonte: BIESKI, 2005.

Família: Lamiaceae

Sinonímia: Hortelã pimenta (M. piperita). M. rotundifolia: erva boa; hortelã cheirosa; hortelã chinesa; hortelã comum; hortelã cultivada; da horta; de cavalo; de folha; hortelã de folha miúda; hortelã de panela; hortelã rasteira; mentrasto; poejo.

Origem: Inglaterra.

Descrição: É uma planta herbácea tem de 30 a $60 \mathrm{~cm}$ de altura, ligeiramente aveludada; haste quadrangular, aveludada, ramosa; ramos opostos, aromáticos; folhas opostas, curtamente pecioladas, oval arredondada, lanceolada ou acuminada, serrada, algo pubescentes; inflorescência em espiga terminal; flores violáceas, numerosas, curtamente pedunculadas, reunidas em verticilos separados. Existem cerca de 25 espécies do gênero mentha. Dada a facilidade de hibridação do gênero Mentha 
não se recomenda o cultivo de diversas espécies de hortelã lado a lado.

Uso farmaco-terapêutica: Gases, vermífugo, analgésica, anti-séptica, anti-espasmódica, antiemética, colagogas, estomáquica, antiinflamatória, tônica.

Propagação: Por estacas.

Parte utilizada: Folhas

Constituintes químicos principais: Óleo essencial 0,7 a 3\% que contém Mentol (40-60\%), cineol (6-8\%), mentona (8-10\%), mento furano (1 a $2 \%)$, pineno, limoneno e mentonapiperitona.

Formas farmacêuticas habituais: Salada natural; infusão; decocção (chás).

Indicação, Preparo e Posologia: folhas e ramos consumidos em saladas ao natural; o chá das folhas e ramos é estimulante digestivo, intestinal anti- séptico, cardiotônico, gelactagogo, antiespasmódico, carminativa, colagogo, usado contra litíase, gastrite e reumatismo, atonia das vias digestivas, flatulências, timpanite principalmente nervosa, cálculos biliares, icterícia, palpitações, tremedeiras, vômito por nervosismo, cólicas uterinas, dismenorréia e prostatite.

Chá por infusão: folhas e flores $15 \mathrm{~g}$ de folhas em um litro de água. Tomar 4 a 5 xícaras por dia. Vermes: chá por infusão 2 xícaras em jejum, por uma semana;

Fadiga geral;

Dores dentárias (bochechos);

Sauna facial para nevralgias faciais provocadas pelo frio: $25 \mathrm{~g}$ de folhas em $500 \mathrm{ml}$ de água fervente. Expor o rosto aos vapores, cobrindo a cabeça com uma toalha.

Observações: Há várias espécies de Mentha com propriedades medicinais. Destaca-se a Mentha piperita; Mentha arvensis; Mentha rotundifolia; Mentha spicata. 


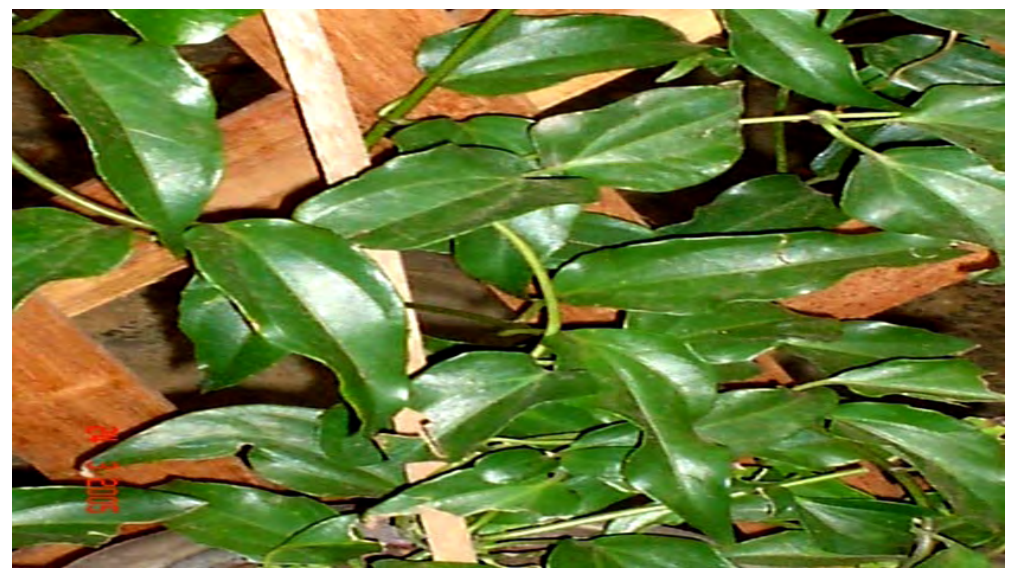

Figura 14. Mikania glomerata Spreng (Guaco)

Fonte: BIESKI, 2005.

Família: Asteraceae

Sinonímia: Guaco liso, guaco de cheiro, cipó caatinga, cipó suciriju, coração de Jesus, erva de cobra, uaco, guape.

Origem: América Tropical

Descrição: Planta trepadeira. Caule delgado e cilindro. Folhas de guaco é peciolada, oval-lanceolada, opostas, simples, ovais, acuminadas. Inflorescências em pequenos capítulos longipedunculados. Flores brancas. Os ramos e folhas são assaz e aromáticas. Prefere solos ricos em matéria orgânica

Uso farmaco-terapêutico: Broncodilatador, antiasmática, expectorante, diurética, tônica, peitoral, emoliente, depurativa, cicatrizante, albuminúrias, febres, reumatismo e sífilis.

Propagação: Por enraizamento de ramos herbáceos.

Parte utilizada: Folhas.

Constituintes químicos principais: Heterósida, guacosídeo, guacina (substância amarga), taninos, resinas, saponinas, cumarinas.

Formas farmacêuticas habituais: Infuso, decocto, extrato fluido, tintura, elixir, vinho, xarope.

Indicação, Preparo e Posologia: Afecções do aparelho respiratório: tosses rebeldes, bronquites, asma, rouquidão. Antiofídicas, inflamações de garganta, eczema pruriginoso, resfriado febril, peitoral. O óleo essencial age como um poderoso antiinflamatório do aparelho respiratório. 
Infuso ou Decocto- de 50 a $200 \mathrm{ml} /$ dia de chá tomar de 2 a 3 vezes ao dia;

Extrato fluido-Tomar de 2 a 4 colheres de chá ao dia;

Elixir-de 20 a $80 \mathrm{~g}$ de chá, tomar 1 ao dia;

Xarope 10 a $40 \mathrm{ml} / \mathrm{dia}$. Contra a tosse e bronquite: fazer um xarope, ferver 6 folhas picadas em um litro de água, coar, misturar o suco de um limão, 3 colheres de sopa de mel. Tomar um cálice 4 vezes ao dia.

Observação: Não é indicado para crianças menores de um ano de idade. E para mulheres na época de menstruação é contra-indicado, pode aumentar o fluxo sanguínea.

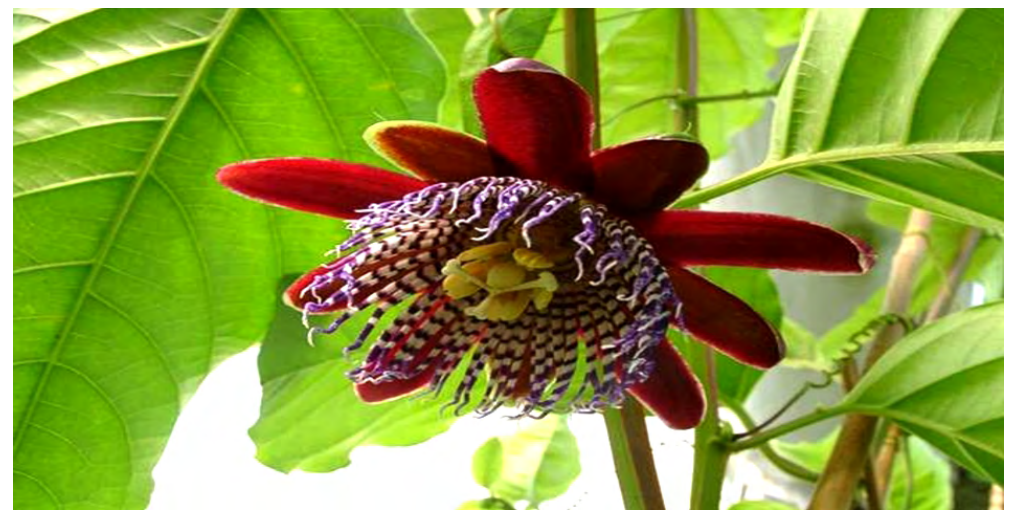

Figura 15. Passiflora alata Dryand (Maracujá)

Fonte: BIESKI, 2005.

Família: Passifloraceae

Sinonímia: flor da paixão, maracuhá Açu, maracujá amarelo, maracujá comprido, maracujá comum de refresco, maracujá mamão, maracujá melão, maracujá silvestre, maracujá suspiro, passiflora.

Origem: América tropical

Descrição: É uma planta trepadeira, perene, arbustiva sarmentosa, atingindo de 8 a 10m de altura quando se apóia em árvores altas. Caule quase quadrangular, estreitamente alado, glabro. Folha simples, grande, alterna, trilobuladas, palminérveas, verde escuro. Contém pecíolo de 2,5 a 3,0 cm de comprimento nas folhas adultas. Flores grandes, pendentes, abertas com 11 a $17 \mathrm{~cm}$ de diâmetro; sépalas sub-carnosas, oblongo-obtusas, no verso perto do ápice, 
corniculadas, por fora verde e por dentro avermelhada; pétalas mais longas do que as sépalas. Frutos ovais ou oblongos, às vezes redondos, casca grossa e muito lisa amarela. Sementes pequenas, cinza escuro, achatadas e numerosas. Adapta-se a climas quentes e úmidos e prefere solos ricos em matéria orgânica. Não tolera solos encharcados.

Uso farmaco-terapêutica: sedativo, tranquilizante, antiespasmódico, diurético. Dores de cabeça de origem nervosa, ansiedade, insônia asma, nevralgias.

\section{Propagação: Sementes}

Parte utilizada: Folhas, frutos e sementes (arilo).

Constituintes químicos principais: Alcalóides indólicos (harmana, harmina, harmol,

harmalina), esteróides, glicosídeos, flavonóides (vitexina, isvitexina, orientina, apigenina), oxicumarinas, sais minerais, saponina e pectina.

Formas farmacêuticas habituais: infusão, decocto.

Indicação, Preparo e Posologia: Devido aos alcalóides e flavonóides, o maracujá age como depressor inespecífico do sistema nervoso central, resultando em uma ação sedativa, tranquilizante e antiespasmódica da musculatura lisa.

Uso interno: infuso ou decocto a $1 \%$ tomar 50 a $200 \mathrm{ml}$ por dia.

Extrato fluido em álcool 25\%: 0,5 a $1 \mathrm{ml}$ três vezes ao dia. Tintura: 1:8 em álcool 45\% - 0,5 a $2 \mathrm{ml}$ três vezes ao dia. Pó: 0,25 a $1 \mathrm{~g}$ três vezes ao dia ou por infusão.

Uso externo: para artritismo e gota: Chá por decocção sob a forma de banhos quentes ou sob forma de cataplasma. Hemorróidas - uso externo: Folhas trituradas, aplicadas sobre os tumores hemorroidais, ou chá por decocção, sob a forma de clister. 


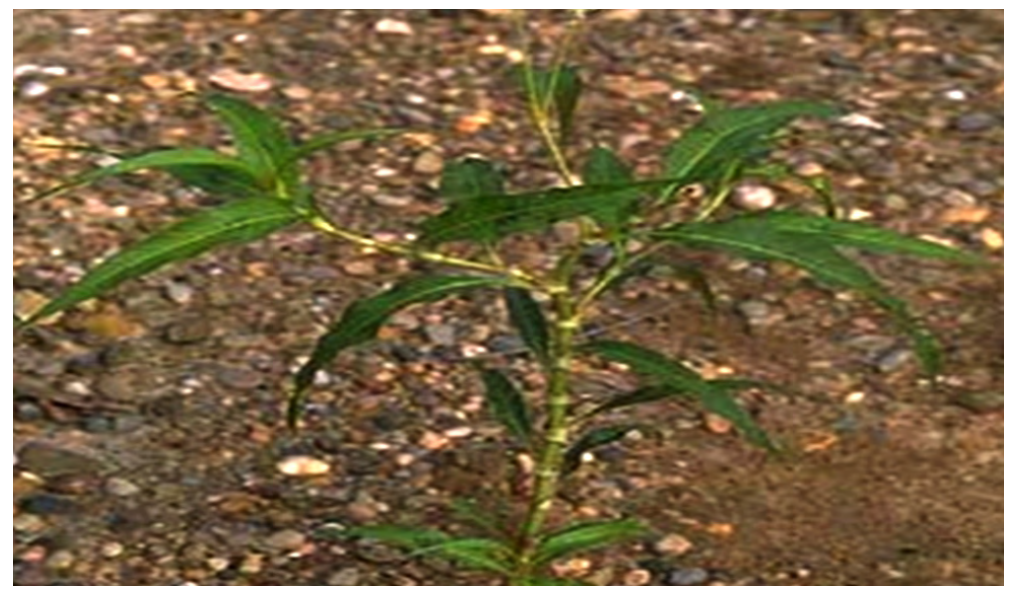

Figura 16. Polygonum acre H.B.K. (Erva-de-bicho) Fonte: BIESKI, 2005.

Família: Polygonaceae

Sinonímia: Capetiçoba, cataria, pimenta-do-brejo, pimenta d'água, catala, capiçoba, percicária-do-Brasil, petincobe, potincoba, erva pulgueira.

Origem: Ásia.

Descrição: Planta erbácea, com caule ereto ou ascendente, com até 1 metro de altura, glabra; folhas alternas, subsésseis, lanceoladas, acuminadas, glandulosas, estípulas axilares, estreitas, esparsamente pilosas; inflorescência em espigas terminais, filiforme, barateadas, cálice glanduloso, fruto núcula trígona. Prefere lugares úmidos e águas pouco profundas.

Uso farmaco-terapêutica: antiséptica, adstringente, antiinflamatória, hipotensora, anti-hemorroidal.

Propagação: Sementes e enraizamento de ramos herbáceos.

Parte utilizada: Toda planta.

Constituintes químicos principais: Óleos essenciais, flavonóides (rutina, quercitina e luteolina), Tanino, ácido poligônico, poligonona e uma glicósida.

Formas farmacêuticas habituais: Infuso, decocto, extrato fluido, tintura, xarope etc.

Indicação, Preparo e Posologia: Diurética, úlcera, cicatrizante, vermicida, hemorróidas, usada também para reumatismo, erisipela e artrite (uso externo). 
Banho de assento-ferver por 10 minutos $100 \mathrm{~g}$ da planta seca em 2 litros de água, coar e banhar a região anal por 30 minutos massageando levemente; repetir o tratamento 3 vezes ao dia, para (hemorróidas);

Compressa-aplicar a infusão descrita a seguir, sobre a região dolorida por algumas horas (reumatismo);

Infusão-(uso externo) 3 colheres da planta seca em $1 / 2$ litro de água, embeber em gaze e aplicar sobre o ferimento (cicatrizante);

Infusão-(uso interno) colocar 3 colheres (sopa) da planta fresca em 1 litro de água. Tomar 3 xícaras de (chá) ao dia.

Observações: Outra espécie Polygonum hydropiperoides Michaux L. também apresenta princípios ativos semelhantes.

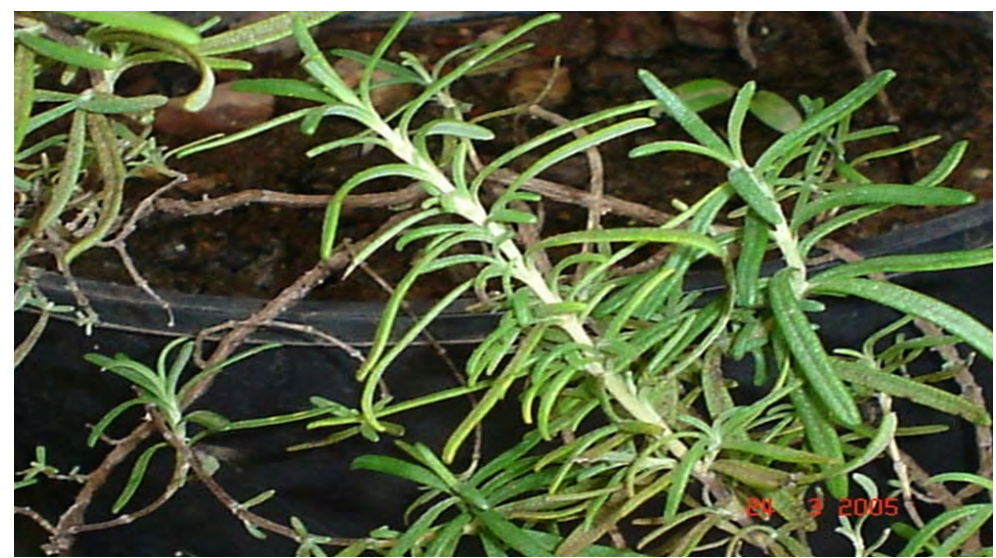

Figura 17. Rosmarinus officinalis L. (Alecrim)

Fonte: BIESKI, 2005

Família: Lamiaceae

Sinonímia: Alecrim-de-jardim; Rosmarino; Libanotis; Alecrim-de-cheiro; Alecrim-de-horta

Origem: Sul da Europa e Norte da África.

Descrição: Subarbusto ramificado de até $2 \mathrm{~m}$ de altura dependendo do cultivo. As folhas são opostas cruzadas, sésseis, lineares, coreáceas, espessas, lanceoladas, de bordos recurvados, de 2 a $3 \mathrm{~cm}$ de comprimento. A fase superior é verde-acinzentada, glabra, um pouco lustrosa e finamente reticulada; a face inferior é recoberta de pêlos estelares, que lhe dão um aspecto tomentoso e coloração esbranquiçada. Inflorescências em cachos curtos, dispostos nas 
axilas das folhas. As flores, de cálice bilabiado, apresentam uma corola de cor azul-pálida ou lilás, manchalábio superior bífido e o inferior trilobado. Cheiro aromático, canforáceo, mormente na planta fresca. Sabor levemente aromático e amargo. Prefere climas temperados quentes, e regiões de dias longos com bastante luminosidade. Tem alta capacidade de retirar nutrientes do solo, prefere solos secos, arenosos e bem drenados. Em solos ricos em nutrientes as folhas. apresentam menor teor de essência aromática. Espaçamento entre linhas 0,80 a 1,00 e entre plantas 0,50 a 0,80m

Uso farmaco-terapêutica: Reumatismo; histeria; tosses; bronquite; Hemorróidas; Cicatrizante; gases intestinais.

Propagação: estacas, ponteiras dos ramos.

Parte utilizada: Folhas secas e sumidades florais.

Constituintes químicos principais: Óleo essencial (Borneol; pineno, canfeno, cânfora, cineol, acetato de bornila); diterpeno (rosmaricina); tanino; saponina; ácidos orgânicos; pigmentos; flavonóides.

Formas farmacêuticas habituais: Infusão; Tintura; Pó cicatrizante, soluto concentrado, xarope etc.

Indicação, Preparo e Posologia: Como tônico do sistema nervoso central, é indicado em casos de esgotamento cerebral, excesso de trabalho e depressão ligeira.

Uso interno: infuso - 20g de planta por 2 litros de água, tomar 2 a 3 xícaras ao dia. Folhas secas -2 a $4 \mathrm{~g}$ três vezes ao dia ou por infusão. Extrato fluido em álcool 45\%: 2 a $4 \mathrm{ml}$ três vezes ao dia.

Uso externo: infuso a $5 \%$. Usado como estimulantes, calmantes das dores. Xampus até $5 \%$ de extrato glicólico. Loções capilares, dentifrícios até $3 \%$ de extrato glicólico.

Observação: o seu uso durante a noite pode alterar o sono. O seu uso em doses elevadas pode provocar irritações gastrintestinais e nefrite.

\section{CONSIDERAÇÕES FINAIS}

A tradição no uso de plantas medicinais no brasil, vem perdendo espaço gradativamente para os medicamentos sinteticos, isso pode estar ocorrendo por influência da própria convivência entre as pessoas e pelo atendimento médico, portanto cabe ao poder 
público intensificar cada vez mais as politicas em prol da inserção da implantação da fitoterapia no brasil e assim reverter esta realidade, através do investimentos em Laboratórios oficinais e magistrais para garantir saúde e serviço no SUS de qualidade e baixo custo.

O uso de plantas medicinais poderá melhorar significativamente a qualidade de vida das famílias, pois além do seu uso, cultivo e comercialização, poderá ser uma alternativa de renda para agricultura familiar. É importante aumentar o apoio à pesquisa científica nesta área e investir mais no cultivo e domesticação das plantas nativas, com isto proteger as espécies do extrativismo predatório. Estudar intensivamente as plantas medicinais no tocante aos seus aspectos etnobotânico, fitoquímico, clínico, buscando um produto de qualidade, conforme designação da ANVISA.

\section{REFERÊNCIAS}

ALEXIADES, M. Selected guidelines for ethnobotanical research: a field manual. New York Botanical Garden, New York. 1996.

ALMEIDA, Edvaldo Rodrigues de Plantas medicinais brasileiras. Conhecimentos populares e científicos. São Paulo, Hemus, 1993.

AMOROZO, M. C. M. Abordagem etnobotânica na pesquisa de plantas medicinais. Pp. 47-68. In: L. C. Di Stasi (Org.). Plantas medicinais: arte e ciência - um guia de estudo interdisciplinar. Ed. UNESP, São Paulo. 1996.

BEGOSSI, A. Etnobotânica em comunidades caiçaras. Pp. 108-120. In: V. S. Fonseca; M. I. Silva \& C. F. C. Sá (Orgs.). Etnobotânica: bases para a conservação. EDUR, Rio de Janeiro. 1998.

BIESKI, I. G. C. JUNIOR, E. G., O MARKETING DA PLANTAS DAS MEDICINAIS NO SUS, Artigo publicação no Anais do Simpósio de Plantas Medicinais do Brasil. Manaus - AM. Anais...2004

BREMNESS, L. Guia prático: plantas aromáticas, culinárias, medicinais e cosméticas. Porto Lisboa: Civilização, 1993. 240 p.

CABELLERO, J. Perpectiva para el quehacer etnobotânico em México. In: Jorge, et al, (2003), Etnobotânica de Plantas Medicinais Diversos olhares em Etnobiologia, Etnoecológia e Plantas Medicinais. 2003.

CARVALHO JÚNIOR, C.; MING, L. C.; SCHEFFER, M. C. Cultivo de plantas medicinais, condimentares e aromáticas. 2. ed. Jaboticabal: FUNEP, 1994. 162 p.

CASTRO, L. O.; CHEMALE, V. M. Plantas medicinais: condimentares e aromáticas. Guairá: Agropecuária, 1995. 194 p. 
CORRÊA, A. D.; BATISTA, R. S.; QUINTAS, L. E. M. Plantas medicinais do cultivo à terapêutica. Petrópolis: Vozes, 1998. 246 p.

CORRÊA, P. Dicionário das plantas úteis do Brasil. 6 vs, Rio de Janeiro. Ministério da Agricultura e IBDF, 1975.

CRUZ, G.L. Livro verde das plantas medicinais e industriais do Brasil. 2vs., Belo Horizonte, Veloso, 1965

FARNSWORTH, N.R. Screening plants for new medicines. In: Wilson, E.O. (ed) Biodiversity Washington DC: Nac. Acad. Press, 521p. 1988.

FITOTERAPIA - Vademecum de prescripción - Plantas medicinales. 3ạ ed., Barcelona, Espanha, Colégio Oficial de Farmacêuticos de Biskaia y Asociación Española de médicos nauristas, Ed. Masson, 1998.

FRANCO, L. L. As sensacionais 50 plantas medicinais: campeãs de poder curativo. 4. ed. Curitiba: [s.n.], 1999. 235 p.

GIULIETTI., Sistema de Informação Sobre Biodiversidade/ Biotecnologia para o Desenvolvimento Sustentável Plano Nacional de Botânica, BDT, 2005.

GUARIM Neto, G. Plantas medicinais do Estado de Mato Grosso. Associação Brasileira de Educação Agrícola Superior, Brasília. 1996.

HERTWIG, F. I. V. Plantas aromáticas e medicinais. 2. ed. São Paulo: Ícone, 1991. 414 p.

LEÃO, M. G., Memento Terapêutico da Fábrica de Medicamento de Mirassol D’Oeste - FAMEM, Secretaria Municipal de Saúde de Mirassol D'Oeste-MT, 1995

LEVI-STRAUSS, C. O uso das plantas silvestres da América do Sul tropical. Suma Etnológica Brasileira 1: 91-94. 1987.

LORENZI, H.; MATOS, F. J. A. Plantas medicinais no Brasil: nativas e exóticas. Nova Odessa: Plantarum, 2002. 512 p.

MARTINS, E. R. Plantas medicinais. Viçosa: UFV, 2000. 220 p.

MATOS, F.J.A. \& Cavalcanti, F.S. \& Queiroz, M.F.F.B. Plantas da medicina popular do Ceará selecionadas pela maior freqüência de seu uso. In: VIII Simpósio de Plantas Medicinais do Brasil. Manaus AM, INPA, Universidade do Amazonas, 1984.

MATOS, J. K. A. Plantas Medicinais - Problemas e Possibilidades. Hort. Bras. I (1): 5-10, 1983.

MENDONÇA, V.L.M., ALII. Anais do X Simpósio de Plantas Medicinais do Brasil. 5/9: 13, Anais...1988.

ROGER, J. D. P. Plantas mágicas: enciclopédia de plantas medicinais. São Paulo: Planeta do Brasil, 1998. 2 v. 84

SIMÕES, C. M. O. Plantas da medicina popular no Rio Grande do Sul. Porto Alegre: UFRGS, 1998. 172 p. 
TESKE, M.; TRENTINI, A. M. Compêndio de fitoterapia: herbarium. 3. ed. Curitiba: Herbarium Laboratório Botânico, 1995. 317 p.

XOLOCOTZY, E. H. El concepto de etnobotânica. Pp. 13-18. In: A. Barrera (Ed.) La etnobotânica: tres puntos de vista y una perspectiva. Xalapa. Inst. Nac.de Investigaciones sobre Recursos Bióticos. 1983. 